\title{
Expression of A Gene Encoding A Functional Glycosyl Hydrolase, Trehalase, from Nicotiana Tabacum in Saccharomyces Cerevisiae
}

Machida, Takeshi

Laboratory of Food Hygienic Chemistry, Division of Food Biotechnology, Department of Bioscience and Biotechnology, Faculty of Agriculture, Graduate School, Kyushu University

Honjoh, Ken-ichi

Laboratory of Food Hygienic Chemistry, Division of Food Biotechnology, Department of Bioscience and Biotechnology, Faculty of Agriculture, Graduate School, Kyushu University

Shimizu, Hideyuki

Laboratory of Food Hygienic Chemistry, Division of Food Biotechnology, Department of Bioscience and Biotechnology, Graduate School of Bioresource and Bioenvironmental Sciences, Kyushu University

Yamamoto, Maiko

Laboratory of Food Hygienic Chemistry, Division of Food Biotechnology, Department of Bioscience and Biotechnology, Graduate School of Bioresource and Bioenvironmental Sciences, Kyushu University

他

https://doi.org/10.5109/16107

出版情報: 九州大学大学院農学研究院紀要. 54 (2)，pp.297-303，2009-10-29. Faculty of Agriculture, Kyushu University

バージョン：

権利関係 : 


\title{
Expression of A Gene Encoding A Functional Glycosyl Hydrolase, Trehalase, from Nicotiana Tabacum in Saccharomyces Cerevisiae
}

\author{
Takeshi MACHIDA, Ken-ichi HONJOH*, Hideyuki SHIMIZU' ${ }^{1}$, Maiko YAMAMOTO', \\ Masayoshi IIO and Takahisa MIYAMOTO
}

\author{
Laboratory of Food Hygienic Chemistry, Division of Food Biotechnology, Department of \\ Bioscience and Biotechnology, Faculty of Agriculture, Graduate School, \\ Kyushu University, Fukuoka 812-8581, Japan \\ (Received June 11, 2009 and accepted July 13, 2009)
}

\begin{abstract}
Trehalases (TREs) function in trehalose hydrolysis and commonly found in most organisms. It is said that most fungi have two types of TREs, acid trehalase and neutral trehalase, but other organisms including plants have only one type. To investigate the function of TRE from plants, a full-length cDNA clone encoding TRE was isolated and designated NtTRE. A conserved region of common trehalase can be found in deduced amino acid sequence of NtTRE, thus the gene was recognized to encode NtTRE enzyme. The $N T T R E$ was expressed in Escherichia coli as a glutathione-S-transferase (GST)-fusion protein to investigate the function of the expressed protein as trehalase. SDS-PAGE profile of the protein extract of $E$. coli showed that the expressed GST-NtTRE protein appeared to be cleaved into two polypeptides, which were approximately 56 and $28 \mathrm{kDa}$ in size, and to form an inclusion body. Based on the results of N-terminal amino acid sequencing of the 56-kDa protein, it contained almost all parts of NtTRE protein. Thus, the protein expressed in $E$. coli was used only for production of anti-NtTRE antibodies. Function of NtTRE was investigated using yeast expressing NtTRE. The NtTRE protein was expressed as a soluble protein. Trehalase activity of protein extract of the transformed yeast was significantly higher than that of control yeast carrying an empty vector. In addition, intracellular trehalose content in yeast cells was significantly reduced by expression of NtTRE. Those data provided a possibility to construct a modified tobacco plant that can accumulate trehalose in the cells by suppression of the expression and/or the activity of NtTRE.
\end{abstract}

\section{INTRODUCTION}

Trehalose is a soluble, non-reducing disaccharide of glucose. It is found in a large variety of microorganisms and invertebrate animals, and can serve as a stress protectant (Elbein, 1974). For example, it can play roles in protection of cells against denaturation of proteins and fusion of membranes to stabilize proteins and membranes under stress conditions, especially under desiccation and heat stress (Wingler, 2002). It is expected that accumulation of a large amount of trehalose enables to enhance stress tolerance of plants and thus the technique helps the world out of anticipated food crises.

Trehalose is synthesized via two enzymatic steps catalyzed by trehalose 6-phosphate synthase (TPS), which generates trehalose 6-phosphate (T6P) from UDPglucose and glucose 6-phosphate, and trehalose 6-phosphate phosphatase (TPP), which generates trehalose from T6P (Londesborough and Vuorio, 1993), and its degradation into two molecules of glucose is mediated by trehalase (Elbein, 1974). Most plants have not been considered to accumulate trehalose (Müller et al., 1995) in spite of trehalose accumulation has been found in bacteria, animals, and fungi. As a few exceptions, trehalose has been detected in resurrection plants, such as Selaginella lepidophylla and Myrothamnus flabellifo-

\footnotetext{
Laboratory of Food Hygienic Chemistry, Division of Food Biotechnology, Department of Bioscience and Biotechnology, Graduate School of Bioresource and Bioenvironmental Sciences, Kyushu University
}

* Corresponding author (E-mail: honjoh@agr.kyushu-u.ac.jp) lia, which accumulate a large amount of trehalose as a stress protectant (Adams et al., 1990; Müller et al., 1995). Also in other higher plants, such as Arabidopsis thaliana and Solanum tuberosum, trehalose can be detected at very low levels in the presence of the inhibitor of TRE (Goddijin et al., 1997; Vogel et al., 2001). Those reports suggest that plants can synthesize trehalose but it is not accumulated in the cells because of those TRE activities. Thus, suppression of TRE expression may lead to enhance trehalose accumulation even in plants.

To construct a modified higher plant that can accumulate trehalose, a gene encoding TRE was isolated from a tobacco plant, Nicotiana tabacum. The gene, designated NtTRE, was expressed in Escherichia coli as a glutathione- $S$-transferase (GST)-fusion protein to obtain a large amount of recombinant NtTRE protein for production of anti-NtTRE antibodies. The gene was also expressed in Saccharomyces cerevisiae to check whether the NtTRE can hydrolyze trehalose into glucose in eukaryotic cells.

\section{MATERIALS AND METHODS}

\section{Strains and conditions}

A tobacco plant (Nicotiana tabacum var. Samsun) was cultured on a MS agar medium (Murashige and Skoog, 1962) supplemented with $0.8 \%$ (w/v) agar and $3 \%(\mathrm{w} / \mathrm{v})$ sucrose in a growth chamber (LX-3000; TAITEC, Tokyo, Japan) at $25^{\circ} \mathrm{C}$ under a photosynthetic photon flux density of about $70 \mu \mathrm{mol} / \mathrm{m}^{2} \mathrm{~s}$ with a $16 \mathrm{~h}$ photoperiod.

Escherichia coli strain used for expression of 
NtTRE was BL21(DE3)pLysS (Novagen, Madison, WI, USA).

Saccharomyces cerevisiae YPH500 strain (Mata, ura3-52, lys2-801 amber, ade2-101 ${ }^{\text {ochre }}, \quad \operatorname{trp} 1-463$, his3-4200, leu2-41; Stratagene, La Jolla, CA, USA) was used to construct a yeast transformant expressing NtTRE gene. The transformant was screened onto a tryptophan-deficient synthetic raffinose (SR-Trp) agar plate, which contained $0.67 \%(\mathrm{w} / \mathrm{v})$ yeast nitrogen base (Difco Laboratories, Detroit, MI, USA), 2\% (w/v) raffinose, $1.5 \%(\mathrm{w} / \mathrm{v})$ agar, and $0.2 \%(\mathrm{w} / \mathrm{v})$ complete supplement mixture (CSM) without His, Leu, Trp, and uracil supplemented with $0.02 \%(\mathrm{w} / \mathrm{v})$ histidine, $0.02 \%(\mathrm{w} / \mathrm{v})$ leucine, and $0.01 \%(\mathrm{w} / \mathrm{v})$ uracil.

\section{Isolation of poly(A) $)^{+}$RNA}

Total RNA was isolated from tobacco leaves using sepasol-RNA I (Nacalai Tesque, Kyoto, Japan). Cut leaves were ground in liquid nitrogen using mortar and pestle. The powder was suspended in $1 \mathrm{ml}$ of sepasolRNA I using a vortex mixer. The suspension was then incubated at $50^{\circ} \mathrm{C}$ for $10 \mathrm{~min}$, placed for $5 \mathrm{~min}$ at room temperature, mixed with $100 \mu \mathrm{l}$ of chloroform, and placed for $3 \mathrm{~min}$ at room temperature. The sample was centrifuged at $12,000 \times \mathrm{g}$ for $5 \mathrm{~min}$ at $4{ }^{\circ} \mathrm{C}$ and total RNA in the supernatant was precipitated with 2-propanol. The precipitate was resuspended in a mixture of $600 \mu \mathrm{l}$ of RNase-free water, $100 \mu \mathrm{l}$ of $5 \mathrm{M} \mathrm{NaCl}$, and $80 \mu \mathrm{l}$ of cetyltrimethyl ammonium bromide (CTAB) solution containing $10 \%(\mathrm{w} / \mathrm{v}) \mathrm{CTAB}$ and $0.7 \%(\mathrm{w} / \mathrm{v}) \mathrm{NaCl}$, and then incubated at $65^{\circ} \mathrm{C}$ for $10 \mathrm{~min}$. The suspension was mixed with an equal volume of a mixture of chloroform and isoamyl alcohol $(24: 1, \mathrm{v} / \mathrm{v})$, and centrifuged at $12,000 \times \mathrm{g}$ for 5 min at $4{ }^{\circ} \mathrm{C}$. After centrifugation, the aqueous layer was recovered. Total RNA in the aqueous layer was precipitated with 2-propanol, and the precipitate was dissolved in TE buffer containing $10 \mathrm{mM}$ Tris- $\mathrm{HCl}(\mathrm{pH} \mathrm{8.0)}$ and $1 \mathrm{mM}$ EDTA. Poly $(\mathrm{A})^{+}$RNA was purified using the PolyATract mRNA Isolation System III (Promega, Madison, WI, USA) according to the manufacturer's instructions.

\section{PCR amplification of partial cDNA fragment of NtTRE}

Poly (A) ${ }^{+}$RNA (150 ng) was reverse-transcribed into first-strand cDNA with oligo (dT) primer and Reverscript I (Wako Pure Chemical Industries, Osaka, Japan) according to the manufacturer's instructions. The synthesized first-strand cDNA was used as a template in the PCR using degenerated primers, NtTRE1 (5'-TT(T/C) AGA GA(A/G) GTT TAT TAC TGG GAT CC-3') and NtTRE3 (5'-GCC CA(T/C) CCA TT(T/C) GGA (A/G)A(A/G) TCC $\mathrm{CA}(\mathrm{T} / \mathrm{C}) \mathrm{TG}-3$ '), which were designed based on the conserved regions of deduced amino acid sequences of TRE genes from several higher plants. PCR amplification was performed using Ex Taq DNA polymerase (Takara, Kyoto, Japan) with the conditions recommended by the manufacturer. The amplified PCR products were purified from agarose gel slices using a QIAquick Gel Extraction Kit (Qiagen, Venlo, Netherlands). The purified PCR product was subcloned into a pGEM-T easy vector (Promega).
The plasmid generated was used in the transformation of $E$. coli DH5a strain by the method of Hanahan (1983). Nucleotide sequence of the PCR product was determined using an ALF express sequencer (Amersham Pharmacia Biotech, Uppsala, Sweden) by the use of an AutoSequencer Core Kit (Toyobo, Tokyo, Japan) according to the method of Sanger et al. (1977).

\section{Rapid amplification of cDNA ends (RACE)}

The full-length cDNA sequence of NtTRE was determined by 5'- and 3'-RACE procedures. For 3'-RACE, first-strand cDNA was synthesized using Reverscript I, oligo(dT) primer with 3'-adapter sequence (5'-TGG AAG AAT TCG CGG CCG CAG GAA T17-3'). First PCR was performed with primers, TRE7 (5'-GTT GCA CGG TTT ACA GAA GCT TCT-3') and adapter primer (5'-TGG AAG AAT TCG CGG CCG CAG-3'), to amplify the 3'-unknown DNA region. Nested PCR was performed with primers, TRE4 (5'-CAG CAA CAC ATC CGA GGA TAT TTA-3') and adapter primer, using the diluted first PCR product as a template.

For 5'-RACE, first-strand cDNA was synthesized using a 5'-Full RACE Core Set (Takara) with a 5'-phosphorylated primer TRE8 (5'-pCCA CAT AGC ATA GTA TCG ACT C-3'). The synthesized CDNA was ligated using T4 RNA ligase (supplied in the kit) to generate a concatemer of the cDNAs. The 5'-unknown region of NtTRE was amplified with primers, S1-TRE9 (5'-GGA CTT GGT TAG AAG ATC TCT TTC-3') and A1-TRE11 (5'-CAA CAA TCA TTG CAG ACA GGA GAG-3'). Nested PCR was performed with primers, S2-TRE10 (5'-AGT GAC TAT TCA AGA TGC TCA GGG-3') and A2-TRE12 (5'-CTG TTA GTG TAG TAT GCT CGT GCA-3'), using the diluted first PCR product as a template. The RACE fragments were subcloned into a pGEM-T easy vector followed by sequencing as described above.

\section{Sequence analysis}

Homologous proteins to the deduced amino acid sequence of NtTRE were searched using the BLAST program (Altschul et al., 1990) on the National Center of Biotechnology Information web site (http://www.ncbi. nlm.nih.gov/). Alignment of deduced amino acid sequences of TREs from various organisms was constructed with the Clustal W program (http://align.genome. $\mathrm{jp} /$ ).

\section{Plasmid construction and transformation of $E$. coli}

An open reading frame of NtTRE gene was amplified by PCR using two primers with the recognition sites of SalI and NotI, TRE-F-SalI (5'-ACG CGT CGA CTA TGA TTT TCA CTC TGT TTA TAT TAT C-3') and TRE-RNotI (5'-ATA AGA ATG CGG CCG CTC AGT AGC AGT CAA TCT TCA AGT-3'). The recognition sites of SalI and NotI are underlined. The amplified DNA fragment was digested with the corresponding enzymes and introduced into the SalI-NotI site of a pGEX-4T-2 vector (GE healthcare, Heidelberg, Germany) to express NtTRE as a glutathione-S-transferase (GST)-tagged protein. 
The plasmid construct, designated pGEX-4T-2/ NtTRE, was introduced into E. coli BL21(DE3)pLysS by the method of Hanahan (1983). Transformants were screened onto a LB agar plate containing ampicillin (100 $\mu \mathrm{g} / \mathrm{ml})$ and chloramphenicol $(34 \mu \mathrm{g} / \mathrm{ml})$ as selective agents by cultivation at $37^{\circ} \mathrm{C}$ for $18 \mathrm{~h}$. The transformed E. coli was designated BL21/pGEX/NtTRE.

\section{Expression of GST-tagged NtTRE in $E$. coli}

The BL21/pGEX/NtTRE cells were cultured in LB containing ampicillin and chloramphenicol (LB/Amp/ Cam) at $37^{\circ} \mathrm{C}$ overnight. The overnight culture was inoculated into LB/Amp/Cam, and then the inoculated culture was incubated at $37^{\circ} \mathrm{C}$ until the $\mathrm{OD}_{660}$ reached 0.4 . Expression of NtTRE was induced by addition of isopropyl- $\beta$-D-thiogalactopyranoside (IPTG) at a final concentration of $1 \mathrm{mM}$ followed by cultivation at $37^{\circ} \mathrm{C}$ for $3 \mathrm{~h}$. The culture was then centrifuged at $4,000 \times g$ for $10 \mathrm{~min}$ at $4{ }^{\circ} \mathrm{C}$, and the harvested cells were suspended in $20 \mathrm{mM}$ potassium phosphate buffer ( $\mathrm{pH}$ 6.0). The cells were disrupted by sonication using a Tomy Ultrasonic Disrupter UP-201 (Tomy Seiko, Tokyo, Japan) for 6 min at $48 \mathrm{~W}$ with $0.5-\mathrm{s}$ pulses at $0.5-\mathrm{s}$ intervals, and then centrifuged at $20,000 \times g$ for $10 \mathrm{~min}$ at $4{ }^{\circ} \mathrm{C}$. The obtained supernatant and precipitate were subjected to SDSPAGE (Laemmli, 1970) to check the soluble or insoluble expression of GST-NtTRE.

\section{Solubilization of inclusion body}

To recover the recombinant NtTRE from the precipitate of disrupted BL21/pGEX/NtTRE cells, the precipitate was resuspended in $20 \mathrm{mM}$ potassium phosphate buffer ( $\mathrm{pH}$ 6.0) containing 4\% (w/v) Triton X-100. The suspension was incubated at room temperature for $1 \mathrm{~h}$, centrifuged at $20,000 \times g$ for $10 \mathrm{~min}$ at $4{ }^{\circ} \mathrm{C}$, washed twice with sterilized water, and resuspended in $8 \mathrm{M}$ urea. The suspension was incubated at $37^{\circ} \mathrm{C}$ for $1 \mathrm{~h}$ and then centrifuged $\left(20,000 \times \mathrm{g}, 10 \mathrm{~min}, 4^{\circ} \mathrm{C}\right)$ to recover the supernatant containing soluble protein. The soluble protein was dialyzed against water and then lyophilized.

\section{$\mathrm{N}$-terminal amino acid sequencing and purification of NtTRE protein}

The lyophilized protein was dissolved in $30 \mathrm{mM}$ Tris$\mathrm{HCl}(\mathrm{pH} 6.8)$ containing 1\% (w/v) SDS, 20\% (w/v) glycerol, $10 \%$ (v/v) 2-mercaptoethanol, and 0.0005\% bromophenol blue. The sample was boiled for $3 \mathrm{~min}$ and subjected to 10\% SDS-PAGE (Laemmli, 1970). After electrophoresis, the separated protein was electroblotted onto a polyvinylidene difluoride membrane (Towbin et al., 1979). The N-terminal sequence of the solubilized protein was analyzed with a gas-phase protein sequence analyzer (model PPSQ-21; Shimadzu, Kyoto, Japan).

The dissolved protein sample was separately subjected to preparative electrophoresis using a disc preparative electrophoresis apparatus NA-1800 (Nihon Eido, Tokyo, Japan) since the GST-tag was cleaved from the expressed protein based on the result of SDS-PAGE. The purified NtTRE protein was used in the production of anti-NtTRE antibodies raised in rabbit.
Plasmid construction and transformation of yeast

The NtTRE gene was amplified by PCR using two primers with the recognition sites of ClaI and SacI, TREF-ClaI (5'-CCA TCG ATG ATT TTC ACT CTG TTT ATA TTA-3') and TRE-R-SacI (5'-GAT AGA GCT CTC AGT AGC AGT CAA TCT TC-3'). The recognition sites of ClaI and $S a c I$ are underlined. The amplified DNA fragment was digested with the corresponding enzymes and introduced into the ClaI-SacI site of a pESC-TRP vector (Stratagene), which is downstream of the galactoseinducible promotor $P_{\text {GAL10 }}$.

The plasmid construct, designated pESC-TRP/ NtTRE, was introduced into S. cerevisiae YPH500 by the method of Ito et al. (1983). Transformant were screened onto a SR-Trp agar plate at $30{ }^{\circ} \mathrm{C}$ for $3 \mathrm{~d}$. The transformant was designated YPH/pESC/NtTRE.

\section{Expression of $N T T R E$ in yeast and protein extrac- tion}

The transformed yeast cells were cultured overnight in SR-Trp medium with shaking at $30^{\circ} \mathrm{C}$. The overnight cultures were inoculated into SR-Trp containing $2 \%$ galactose to express the introduced gene. After $24 \mathrm{~h}$ of cultivation at $30^{\circ} \mathrm{C}$, the yeast cells were harvested by centrifugation at $1,000 \times g$ for $10 \mathrm{~min}$ and suspended in $20 \mathrm{mM}$ potassium phosphate buffer $(\mathrm{pH} 6.0)$. The cell suspension was mixed with an equal volume of $0.5 \mathrm{~mm}$ diameter glass beads and homogenized for 5 min at $4{ }^{\circ} \mathrm{C}$ with a vortex mixer. The homogenates were centrifuged at $20,000 \times g$ at $4^{\circ} \mathrm{C}$ for $10 \mathrm{~min}$. The soluble cell lysates were recovered and used as protein extracts.

\section{Immunodetection of NtTRE}

The protein extracts were separated by SDS-PAGE and electroblotted onto a nitrocellulose membrane. The membrane was blocked with TTBS (100 mM Tris-HCl buffer (pH 7.5), 0.9\% (w/v) NaCl, and 0.1\% (w/v) Tween 20) containing $3 \%(\mathrm{w} / \mathrm{v})$ skimmed milk. The membrane was treated with rabbit anti-NtTRE antibodies diluted with TTBS containing 3\% skimmed milk. After washing the membrane four times with TTBS, it was incubated with a sheep anti-rabbit IgG-peroxidase conjugate (Dainihonseiyaku, Osaka, Japan), followed by detection of the peroxidase activity in $100 \mathrm{mM}$ Tris-HCl buffer $(\mathrm{pH}$ 7.5 ) containing $0.8 \mathrm{mg} / \mathrm{ml}$ diaminobenzidine, $0.4 \mathrm{mg} / \mathrm{ml}$ $\mathrm{NiCl}_{2}$, and $0.008 \% \mathrm{H}_{2} \mathrm{O}_{2}$. All procedures in this section were performed at room temperature.

\section{Trehalase activity assay}

Trehalase activity of protein extracts of transformed yeast was assayed by the method of Uhaland et al. (2000) with slight modifications. One hundred micrograms of protein extracts of yeast cells cultured in SR-Trp containing $2 \%$ galactose were mixed with $1 \mathrm{mM}$ trehalose, and the mixture was filled up to $300 \mu \mathrm{l}$ with $20 \mathrm{mM}$ potassium phosphate buffer ( $\mathrm{pH}$ 6.0). The mixture was incubated at room temperature for $1 \mathrm{~h}$. After incubation, samples were boiled to stop trehalase reaction and then centrifuged $\left(20,000 \times g, 5 \mathrm{~min}, 4{ }^{\circ} \mathrm{C}\right)$ to remove denatured protein in the samples. Glucose concentrations of 
samples were measured using a F-kit glucose (JK International, Tokyo, Japan). Trehalase activity was expressed as the percentage of trehalose degraded by $100 \mu \mathrm{g}$ of protein (\% trehalose degraded).

\section{Determination of trehalose content}

Trehalase activity was also assayed by determining intracellular trehalose content in yeast cells grown in SR-Trp containing 2\% galactose by the method of Zentella et al. (1999). Yeast cells were harvested by centrifugation $\left(20,000 \times g, 1 \mathrm{~min}, 4^{\circ} \mathrm{C}\right)$, washed three times with water, and lyophilized. The lyophilized cells were suspended in $0.25 \mathrm{M} \mathrm{Na}_{2} \mathrm{CO}_{3}$ at a concentration of $20 \mathrm{mg}$ dried cells $/ \mathrm{ml}$. The suspension was boiled in a water bath for $10 \mathrm{~min}$. After cooling, samples were centrifuged and an aliquot $(200 \mu \mathrm{l})$ of supernatant was mixed with $100 \mu \mathrm{l}$ of $1 \mathrm{M}$ acetic acid to neutralize the solution. Trehalose in the mixture was degraded with $0.125 \mathrm{U}$ of trehalase from porcine kidney (Sigma-aldrich, St. Louis, MO, USA) in buffer $\mathrm{T}\left(0.3 \mathrm{M}\right.$ sodium acetate, $0.03 \mathrm{M} \mathrm{CaCl}_{2}$,
$\mathrm{pH}$ 5.5) at $37^{\circ} \mathrm{C}$ for $1 \mathrm{~h}$. Glucose concentrations of samples were measured using a $\mathrm{F}$-kit glucose, and trehalose content ( $\mu \mathrm{mol} /$ dry cell weight) was calculated according to the manufacturer's instructions.

\section{RESULTS}

\section{Isolation of full-length cDNA clone encoding NtTRE}

To amplify a partial fragment of a cDNA clone corresponding to the TRE gene from N. tabacum, two oligonucleotides were synthesized based on a conserved region of the deduced amino acid sequences of TREs from several organisms. A conserved region of the open reading frame of TRE was amplified by PCR. The amplified DNA fragment, which was $950 \mathrm{bp}$ in size (data not shown), was subcloned into a pGEM-T easy vector to determine the nucleotide sequence. After sequencing of the amplified DNA fragment and confirmation of the fragment as a part of the objective clone, it was used for isolation of a

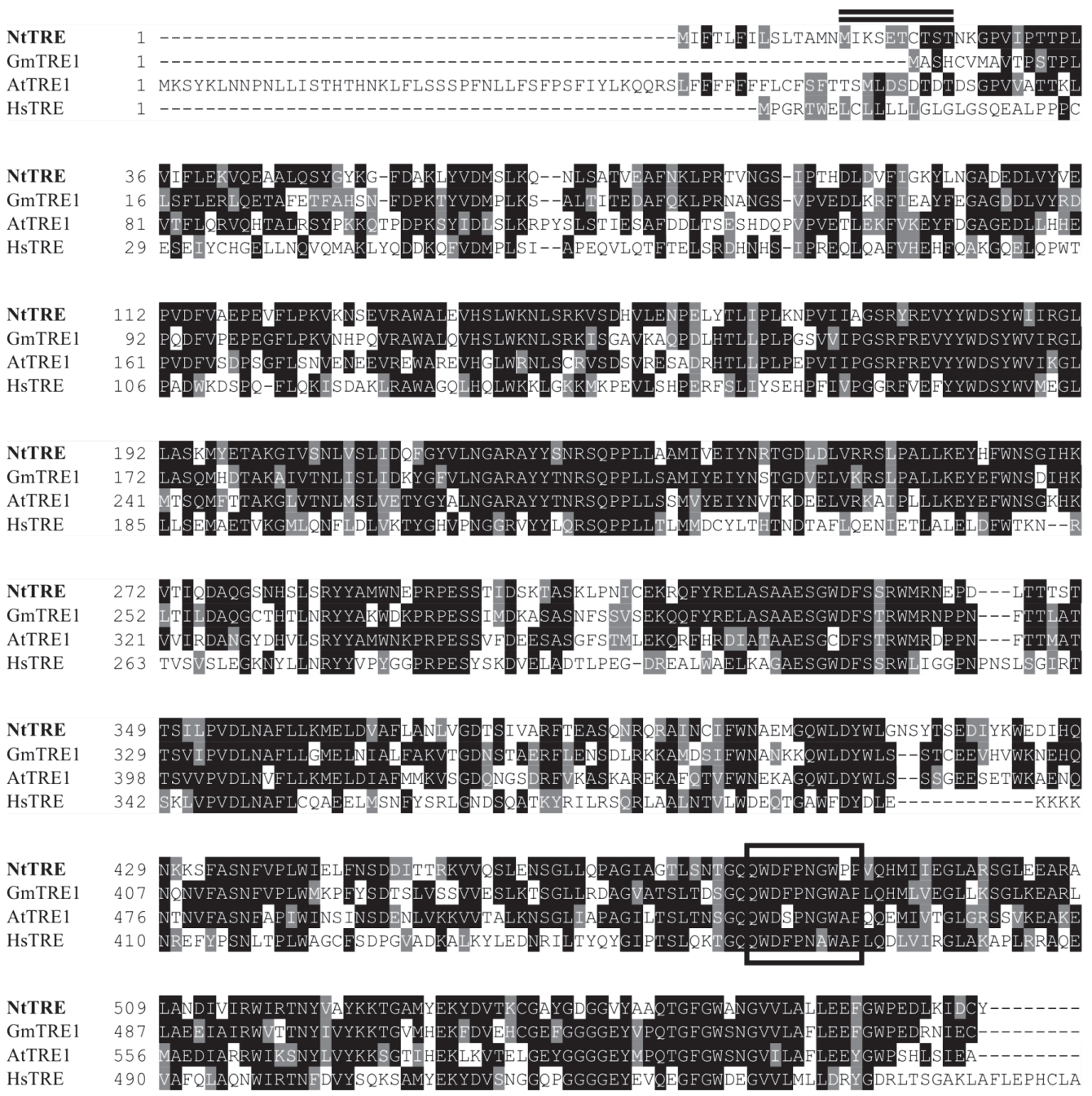

Fig. 1. The alignment of deduced NtTRE and deduced TREs from various organisms was constructed using the Clustal W program (http://align.genome.jp/). Accession numbers for the sequences, shown in parentheses, are as follows: GmTRE1: Glycine max TRE1 (AF124148), AtTRE1: A. thaliana TRE1 (NM_118536), HsTRE: Homo sapiens TRE (AB000824). A conserved region of trehalase (-QWDx[G/A/V]W[P/A/S]P; Kopp et al., 1993) is boxed. N-terminal amino acid sequence $\left(\mathrm{NH}_{2}-\right.$ MIKSETCTST) of 56-kDa NtTRE protein expressed in $E$. coli is double-overlined. 
full-length TRE cDNA clone. To isolate the full-length cDNA clone, 5'- and 3'-RACE procedures were performed, and the full-length cDNA sequence was determined. The tobacco TRE cDNA, designated NtTRE, was $1,977 \mathrm{bp}$ long and contained an open reading frame encoding 580 amino acid residues with a predicted molecular mass of about $65.7 \mathrm{kDa}$ and an isoelectric point of 5.2. The deduced amino acid sequence of NtTRE showed sequence similarity to those of TREs from various organisms (Fig. 1). Furthermore, a conserved amino acid sequence of TRE (-QWDXPX[G/A/V]W[P/A/S]P-; Kopp et al., 1993) was found in the deduced amino acid sequence of NtTRE (Fig. 1). The nucleotide and deduced amino acid sequences of NtTRE were deposited at DDBJ/EMBL/GenBank under accession number AB501123.

\section{Expression of NTTRE in E. coli and purification of the expressed protein}

To produce anti-NtTRE antibodies, NtTRE gene was expressed in E. coli as a GST-fusion protein. E. coli

A

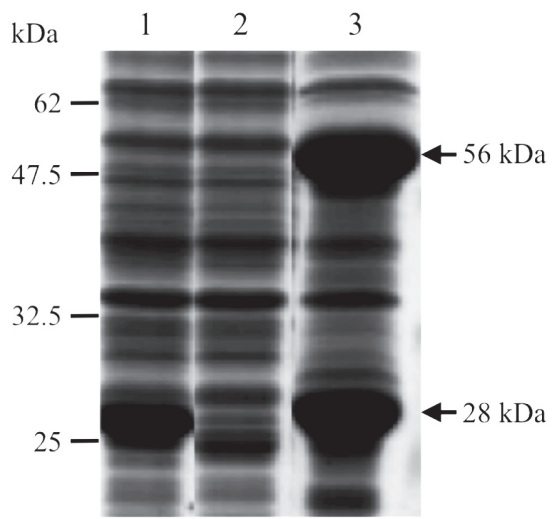

B

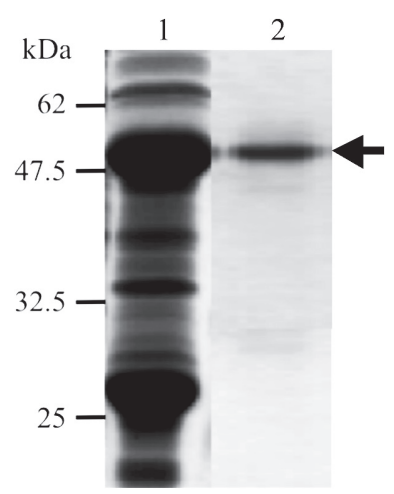

Fig. 2. (A) Expression of NtTRE protein in E. coli was checked by $10 \%$ SDS-PAGE. Lane 1, soluble protein from BL21/ pGEX (empty); lane 2, soluble protein from BL21/pGEX/ NtTRE; lane 3, insoluble protein from BL21/pGEX/NtTRE. (B) The $56-\mathrm{kDa}$ protein was purified using preparative electrophoresis. Lane 1, E. coli insoluble protein; lane 2, purified 56-kDa protein. The arrow indicates a band corresponding to the $56-\mathrm{kDa}$ protein. cells expressing the gene were cultured after addition of $1 \mathrm{mM}$ IPTG at $37^{\circ} \mathrm{C}$ for $3 \mathrm{~h}$. The NtTRE protein was expressed as two separate proteins (Fig. 2A). The proteins were approximately 56 and $28 \mathrm{kDa}$ in size, respectively, as described in Fig. 2A and they seemed to form inclusion body, which are sometimes found in the case of GST-fused expression (Krömer et al., 1997; Bettadapura et al., 1998; Iwata et al., 2000). Thus, the inclusion body was solubilized with $8 \mathrm{M}$ urea and subjected to preparative electrophoresis to purify the $56-\mathrm{kDa}$ protein (Fig. 2B), which would contain NtTRE region abundantly since an $E$. coli carrying an empty pGEX$4 \mathrm{~T}-2$ vector also expressed approximately 28-kDa protein. N-terminal amino acid sequence of the 56-kDa protein $\left(\mathrm{NH}_{2}-\right.$ MIKSETCTST-) was found in the deduced amino acid sequence of NtTRE. Therefore, the 56-kDa protein was thought to contain almost all parts of NtTRE protein, thus antibodies against NtTRE were raised in rabbit using the purified 56-kDa protein as an antigen.

\section{Expression of NtTRE in yeast}

To determine trehalase activity of NtTRE, the corresponding gene was also expressed in $S$. cerevisiae YPH500 by introducing the gene into a pESC-TRP vector. Western blotting and immunodetection using antiNtTRE antibodies showed soluble expression of NtTRE protein in yeast cells (Fig. 3).

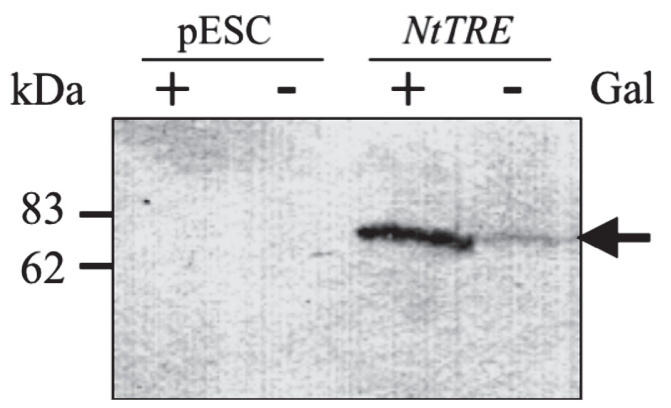

Fig. 3. Protein extracts from yeast cells were separated by SDSPAGE, blotted onto a nitrocellulose membrane, and detected with anti-NtTRE antibodies. Protein was extracted from yeast cell culture with and without galactose (indicated with + and - ). The arrow indicates a band corresponding to NtTRE protein $(65.5 \mathrm{kDa})$.

\section{Trehalase activity of NtTRE expressed in yeast}

Trehalase activity of NtTRE protein was assayed by two methods as described in Materials and Methods. As shown in Fig. 4A, protein extract of YPH/pESC/NtTRE showed significant TRE activity $(59.5 \pm 7.2 \%$ trehalose degraded) when compared to that of control yeast (YPH/ pESC; 39.4 4 4.7\% trehalose degraded). Furthermore, intracellular trehalose content in yeast was reduced significantly by expression of NtTRE gene (Fig. 4B). Trehalose contents in two yeast strains were as follows: $\mathrm{YPH} / \mathrm{pESC}(21.4 \pm 2.4 \mu \mathrm{mol} / \mathrm{g}$ cell dry weight), YPH/ $\mathrm{pESC} / N t T R E(16.2 \pm 2.2 \mu \mathrm{mol} / \mathrm{g}$ cell dry weight). 
A

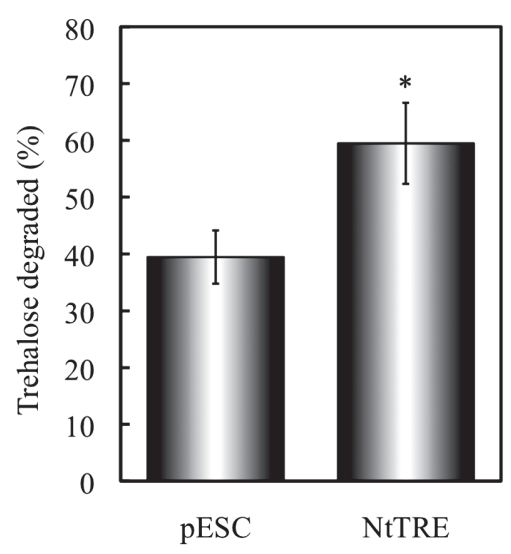

B

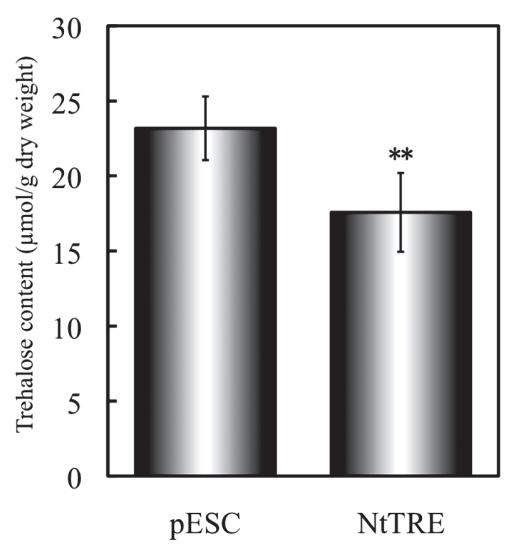

Fig. 4. (A) TRE activity of NtTRE expressed in yeast was assayed using protein extracts of yeast. (B) TRE activity of NtTRE was also assayed by determination of intracellular trehalose content in yeast. Data are means \pm S.D. obtained from three independent experiments. Values with asterisks are significantly different from that of pESC strain at ${ }^{*} p<0.05$ and ${ }^{* *} p<0.01$

\section{DISCUSSION}

Trehalose is known as a cellular protectant against various stresses including freezing stress, therefore, utilization of trehalose for improvement of stress tolerance of agricultural crops has been expected. Accumulation of trehalose has been reported in animals, bacteria, and yeast, and several researchers have achieved accumulation of trehalose in plants and improvement of the stress tolerance by introducing bacterial genes involved in trehalose biosynthesis (Jang et al., 2003). For application of the trehalose accumulation to practical agricultural products, origin of the introduced gene is controversial. Suppression of trehalase activity is a way to accumulate trehalose in plant cells (Goddijin et al., 1997; Vogel et al., 2001). Although several researchers have studied trehalase from plants, improvement of stress tolerance of plants by modifying the TRE gene has not yet been achieved to our knowledge. Furthermore, function of trehalase in plants has not been identified since plants have no or quite little substrate for trehalase (Müller et al., 1995). To gain additional information on trehalase in plants, we isolated and analyzed a gene encoding trehalase from $N$. tabacum. Deduced amino acid sequence of NtTRE contained a conserved region of trehalase and showed high homology to those of TRE genes from plants and other organisms (Fig. 1). Therefore, the NtTRE gene was considered to encode a trehalase in tobacco.

To determine the enzymatic properties of NtTRE, the gene encoding NtTRE was expressed in $E$. coli as a GST-tagged protein. Trehalases are glycosyl hydrolases that exhibit strong substrate specificity for trehalose and identified both in many eukaryotes and prokaryotes (Elbein, 1974). Most fungi have two types of trehalases, acid trehalase and neutral trehalase, that differ in several enzymatic properties such as primary structure, thermostability, and working $\mathrm{pH}$ range (Thevelein, 1984), on the other hand, most bacteria and plants are thought to have only one type of trehalase (Parrou et al., 2005). The GST-NtTRE was expressed as an insoluble protein, however, the expressed protein was detected as two separate proteins, which were 56 and $28 \mathrm{kDa}$ in size, respectively (Fig. 2A). The 56-kDa protein was determined as NtTRE based on its N-terminal amino acid sequence $\left(\mathrm{NH}_{2}-\mathrm{MIKSETCTST}\right)$. It was considered that to purify the protein was difficult and complicated since the protein did not contain the GST-tag, the 56-kDa protein was purified by the disc preparative electrophoresis method, and the purified protein was used only for production of anti-NtTRE antibodies as an antigen. Given such unfavorable results, the function of NtTRE should be investigated in other way.

The NtTRE gene was also expressed in yeast, S. cerevisiae YPH500, using a pESC-TRP vector. Since the NtTRE protein was expressed as a soluble protein (Fig. 3 ), function of the protein as trehalase was examined using the transformed yeast. As shown in Fig. 4A, significantly high trehalase activity was detected in protein extract $(100 \mu \mathrm{g})$ of the transformant when compared to that of control strain. And also, intracellular trehalose amount in yeast was significantly reduced by expression of NtTRE (Fig. 4B). Trehalase is thought to be one of main reasons why trehalose cannot be detected in plants, since some plants can accumulate trehalose when treated with a strong trehalase inhibitor, validamycin A (Müller et al., 1995, López et al., 2009). In addition, the inhibition led to accumulation of trehalose in root nodules of Medicago truncatula and enhanced its salt tolerance (López et al., 2009). Our results and those reports suggest that NtTRE functions in tobacco with high activity to avoid high-level accumulation of trehalose in the cells. Thus, it is expected that trehalose can be accumulated in tobacco by suppression of the expression and the acitivity of NtTRE.

Very low trehalose synthetic activities of TPS and TPP are also considered as a reason that plants cannot accumulate trehalose. Although the genes encoding them have been identified in many plant species and characterized so far, most of the gene products had very low trehalose synthetic activities (Van Dijck et al., 2002). Some researchers have achieved to enhance TPS activity 
by construction of mutated TPS that was excluded its N-terminal extension commonly found in plant TPSs (Zentella et al., 1999; Van Dijck et al., 2002). This technique may be applicable in tobacco TPS and lead to trehalose accumulation in the cells. To investigate it, the genes encoding TPS (and TPP) should be isolated from tobacco in further studies.

In the present study, the NtTRE gene encoding trehalase was isolated from tobacco. The NtTRE protein showed significant trehalase activity when expressed in yeast. Our results provide a possibility to construct a modified tobacco plant that has low level NtTRE activity by gene disruption or antisense suppression techniques. Combined effect of overexpression of TPS and TPP genes is also expected. As one of other trials, accumulation of trehalose may be achieved by cultivation of plants under sublethal salt stress condition, since $M$. truncatula showed down-regulation of TRE expression and increased trehalose content under high concentration (150-250 mM) of NaCl (López et al., 2008). Changes in the expression level and the activity of NtTRE under stress condition should be also investigated in further studies.

\section{ACKNOWLEDGMENT}

The authors are grateful to Dr. M. Nakao of Kyushu University for amino acid sequencing.

\section{REFERENCES}

Adams, R. P., E. Kendall and K. K. Kartha 1990 Comparison of free sugars in growing and desiccated plants of Selaginella lepidophylla. Biochem. Syst. Ecol., 18: 107-110

Altschul, S. F., T. L. Madden, A. A. Schäffer, J. Zhang, Z. Zhang, W. Miller and D. J. Lipman 1997 Gapped BLAST and PSIBLAST: a new generation of protein database search programs. Nucleic Acids Res., 25: 3389-3402

Bettadapura, J., K. K. Meron, S. Moritz, J. Liu and C. C. A. Bernard 1998 Expression, purification, and encephalitogenicity of recombinant human myelin oligodendrocyte glycoprotein. $J$. Neurochem., 70: 1593-1599

Elbein, A. D. 1974 The metabolism of a,a-trehalose. Adv. Carbohydr. Chem. Biochem., 30: 227-256

Goddijin, O. J. M., T. C. Verwoerd, E. Voogd, R. W. Krutwagen, P. T. de Graaf, K. van Dun, J. Poels, A. S. Ponstein, B. Damm and J. Pen 1997 Inhibition trehalase activity enhances trehalose accumulation in transgenic plants. Plant Physiol., 133: 181-190

Hanahan, D. 1983 Studies on transformation of Escherichia coli with plasmids. J. Mol. Biol., 166: 557-580

Ito, H., Y. Fukuda, K. Murata and A. Kimura 1983 Transformation of intact yeast cells treated with alkali cations. J. Bacteriol., 153: $163-168$

Iwata, H., M. Yamamoto, A. Hasegawa, K. Kurata and T. Inoue 2000 Expression of porcine interleukin-2 in Escherichia coli. J. Vet. Med. Sci., 62: 1101-1104

Jang, I.-C., S.-J. Oh, J.-S. Seo, W.-B. Choi, S. I. Song, C. H. Kim, Y. S. Kim, H.-S. Seo, Y. D. Choi,, B. H. Nahm and J. K. Kim 2003 Expression of a bifunctional fusion of the Escherichia coli genes for trehalose-6-phosphate synthase ans trehalose-6phosphate phosphatase in transgenic rice plants increases trehalose accumulation and abiotic stress tolerance without stunting growth. Plant Physiol., 131: 516-524

Kopp, M., H. Müller and H. Holzer 1993 Molecular analysis of the neutral trehalase gene from Saccharomyces cerevisiae. J. Biol. Chem., 268: 4766-4774

Krömer, W. J., E. Carafoli and J. E. Bailey 1997 Purification of the cardiac sarcoplasmic reticulum membrane protein phospholamban from recombinant Escherichia coli. Eur. J. Biochem., 248: 814-819

Laemmli, U. K. 1970 Cleavage of structural proteins during the assembly of the head of bacteriophage $\mathrm{T}_{4}$. Nature, 227: $680-685$

Londesborough, J., and O. E. Vuorio 1993 Purification of trehalose synthase from baker's yeast. Eur. J. Biochem., 216 $841-848$

López, M., N. A. Tejera, C. Iribarne, C. Lluch and J. A. HerreraCervera 2008 Trehalose and trehalase in root nodules of Medicago truncatula and Phaseolus vulgaris in response to salt stress. Physiol. Plant., 134: 575-582

López, M., N. A. Tejera and C. Lluch 2009 Validamycin A improves the response of Medicago truncatula plants to salt stress by inducing trehalose accumulation in the root nodules. J. Plant Physiol., in press

Müller, J., T. Boller and A. Wiemken 1995 Trehalose and trehalase in plants: recent developments. Plant Sci., 112: 1-9

Murashige, T. and F. Skoog 1962 A revised medium for rapid growth and bioassays with tobacco tissue cultures. Physiol. Plant., 15: 473-497

Parrou, J. L., M. Jules, G. Beltran and J. François 2005 Acid trehalase in yeasts and filamentous fungi: localization, regulation and physiological function. FEMS Yeast Res., 5: 503-511

Sanger, F., S. Nicklen and A. R. Coulson 1977 DNA sequencing with chain-terminating inhibitions. Proc. Natl. Acad. Sci. USA, 74: 403-410

Thevelein, J. M. 1984 Cyclic-AMP content and trehalase activation in vegetative cells and ascospores of yeast. Arch. Microbiol., 138: 64-67

Towbin, H., T. Staehelin and J. Gordon 1979 Electrophoretic transfer of proteins from polyacrylamide gels to nitrocellulose sheets: procedure and some applications. Proc. Natl. Acad. Sci. USA, 76: 4350-4354

Uhland, K., M. Mondigler, C. Spiess, W. Prinz and M. Ehrmann 2000 Determinants of translocation and folding of TreF, a trehalase of Escherichia coli. J. Biol. Chem., 275: 23439-23445

Van Dijck, P., J. O. Mascorro-Gallardo, M. De Bus, K. Royackers, G. Iturriaga and J. M. Thevelein 2002 Truncation of Arabidopsis thaliana and Selaginella lepidophylla trehalose-6-phosphste synthase unlocks high catalytic activity and supports high trehalose levels on expression in yeast. Biochem. J., 366: $63-71$

Vogel, G., O. Fiehn, L. Jean-Richard-dit-Bressel, T. Boller, A. Wiemken, R. A. Aeschbacher and A. Wingler 2001 Trehalose metabolism in Arabidopsis: occurrence of trehalose and molecular cloning and characterization of trehalose-6-phosphate synthase homologues. J. Exp. Bot., 52: 1817-1826

Wingler, A. 2002 The function of trehalose biosynthesis in plants. Phytochemistry, 60: 437-440

Zentella, R., J. O. Mascorro-Gallardo, P. van Dijck, J. Folch-Mallol, B. Bonini, C. van Vaeck, R. Gaxiola, A. A. Covarrubias, J. Nieto-Sotelo, J. M. Thevelein and G. Iturriaga 1999 A Selaginella lepidophylla trehalose-6-phosphate synthase complements growth and stress-tolerance defects in a yeast tps1 mutant. Plant Physiol., 119: 1473-1482 